\title{
氣候表現に於ける水分本衡の問題
}

〔關" 口武〕

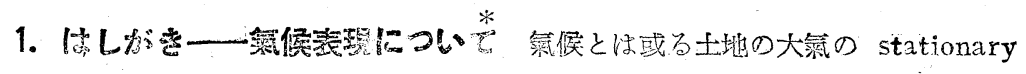

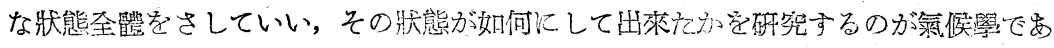

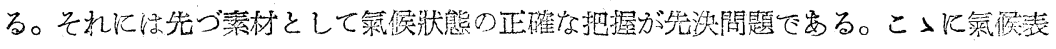

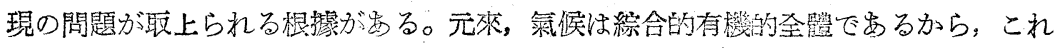
を簡嘿に表現することは他々困難で，現在をで種ふな表現法が工夫せられている。こ

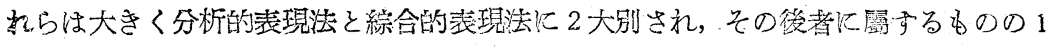

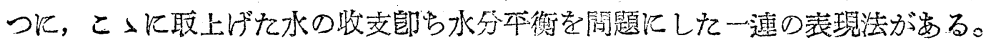

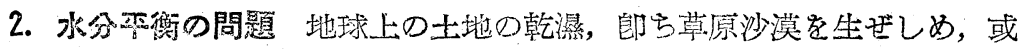

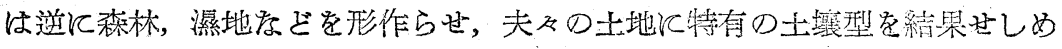
ている土地全體の乾濕の度合は，㽞にとの土地の雨量の多少だけすらは判斷

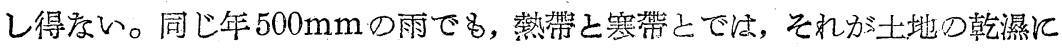
與える影響梳るでらがつて來る。元來土地の乾濕空決定しているのは，そ

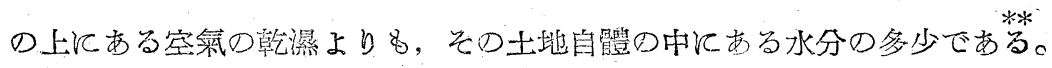

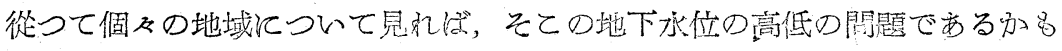

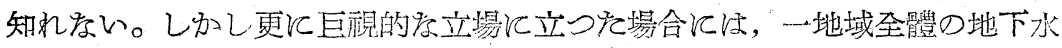
位をやはり土地の乾蒸，即ら土地自體の中に含恋れている水分の量によつて

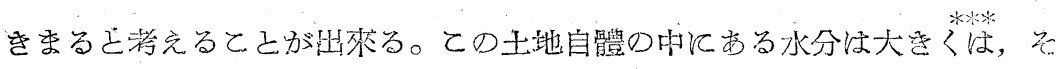

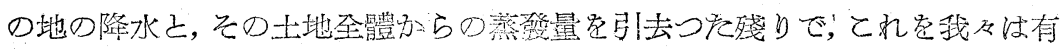

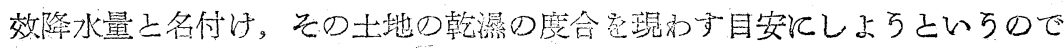

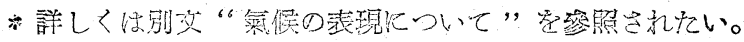

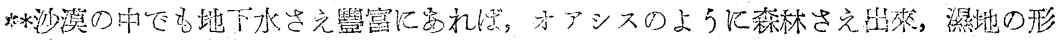

䏺されること尚安る。

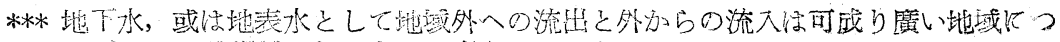

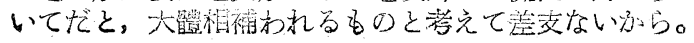




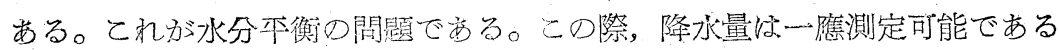

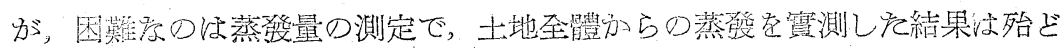

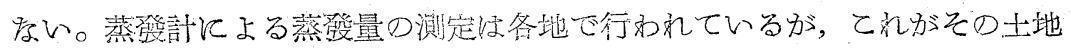

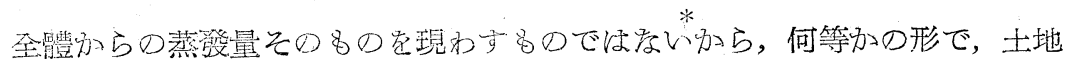

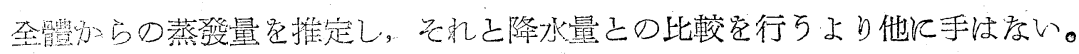

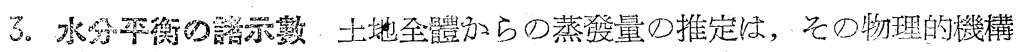

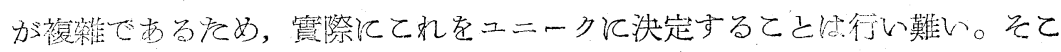

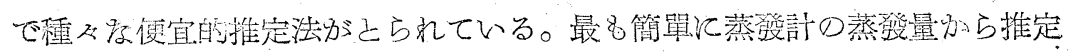

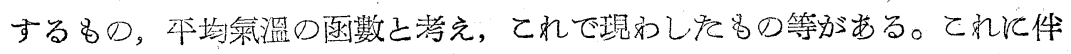

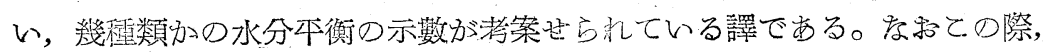
手近几何所でで多得られる氣候資料密使つた方が有利である。又降水量との

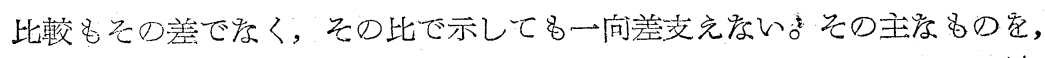

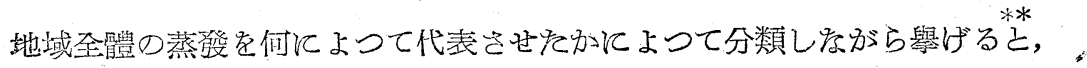

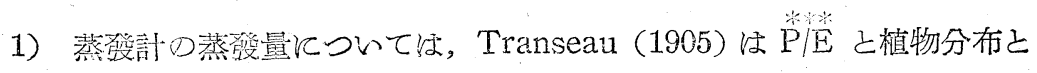
の關係を調心, 融井 (1943) 江乾燥限界 $\mathrm{P} / \mathrm{E}=0.5$ 安つて東亞の乾燥

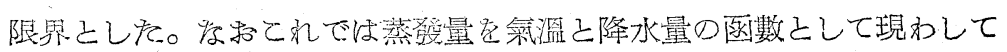
計算している。

2) 飽差については, Meyer (1929) は N-S 係數 P/S 亡土壤型との關 係が密接だという。

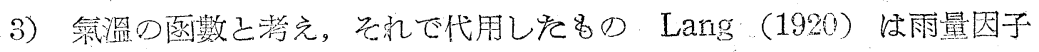

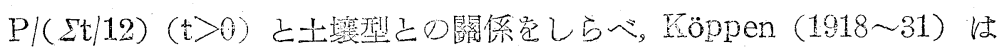

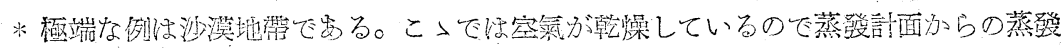

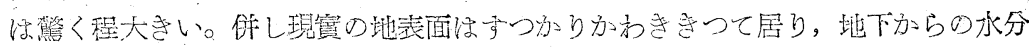

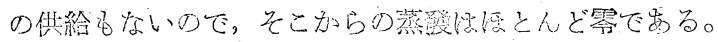

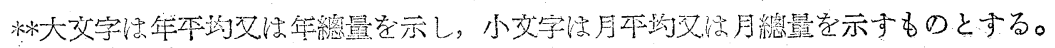

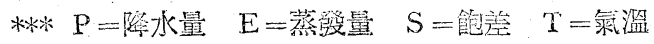


$\mathrm{P} /(\mathrm{T}+\alpha)$ を通常乾燥限界之呼び, $\mathrm{P}=(\mathrm{T}+\alpha) \beta$ の型で與えている。そし て沙漠は $\beta=1$ ，草原は $\beta=2$ がその限界之されている。de Martonne .(1929) は乾燥示數 $\mathrm{P} /(\mathrm{T}+10)$ 乙內部流域, 队陸流域乞の關係を求为, Thornthwaite (1931) \&降水效果示數 $P-E$ index $=\sum^{12} 115(\mathrm{p} / \mathrm{t}-10)^{\frac{10}{9}}$ が植物分布，土壤型と一致をするという。Ångström (1936) の濕度係 數 $\mathrm{P} / 1.07 \mathrm{~T}$ や，雨溫圖（ハイサーグラフ）一 $\rho, \mathrm{t}$ 学兩軸㳊取つて描いた クライモグラフーも用いられている。

4) 水張, 氣溫, 氣壓の函数としたもの一Szymkiewicz (1925) の P/E$\mathrm{e}=\left(\mathrm{b}^{\prime}-\mathrm{b}\right) \frac{273+\mathrm{t}}{273} \cdot \frac{760}{\mathrm{~B}-\mathrm{b}^{\prime}}$

$b^{\prime}$ : 氣溫 $\mathrm{t}$ の時の最大水張 $\mathrm{b}:$ 測定された水張 $\mathrm{t}:$ : 測定された氣温 B : 測定された氣壓

5）河川の流量（R）を利用したものには，Wallén，A. (1927）の $\mathrm{P} / \mathrm{E}$, $E=\rho-R （$ 但し年平均做沉ついてだけ）がある。 等の各種がある。るちろん此等のすべてが，水分本衡という問題空意識し， 意圖的に此等の示數を工夫考案したものではないかも知れない。經驗的に土 壤型の分布，植物分布，或は內陸乾懆地域の分布等飞合致するよらを氣候區 分を行ら目安として選ぱれをものであるかも知れ度い。主要氣候要素である 氣溫己降水量をそだ適賞に機㭜的に組合せて。しかし此等を集めて見ると， その表現形態に多少のちがいはあつても，此等は要すると，水分平衡（有效 降水量）という思想の下に統一するととが出來る。

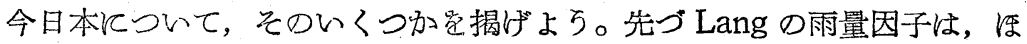
とんぞ全域が 100 以上, それ以下の所謂灌木林, 褐色土に相當する所ね瀨户

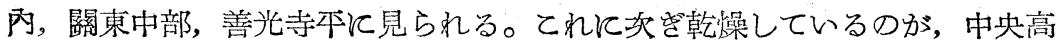
原，關東盆地，濃尾平野，北上川沿いの本地飞見られる。又160以上の濕潤 地域は南海岸沿い，北陸日本海岸沿い及び北海道東部に求められる。この分 
關正

布型は其他の場合にも同檬で, de Martonne の乾燥示數 p/e， Angström ...

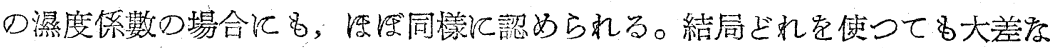
く，它だその目的に應し，一番都合のよい示數を使用すればよいのである。

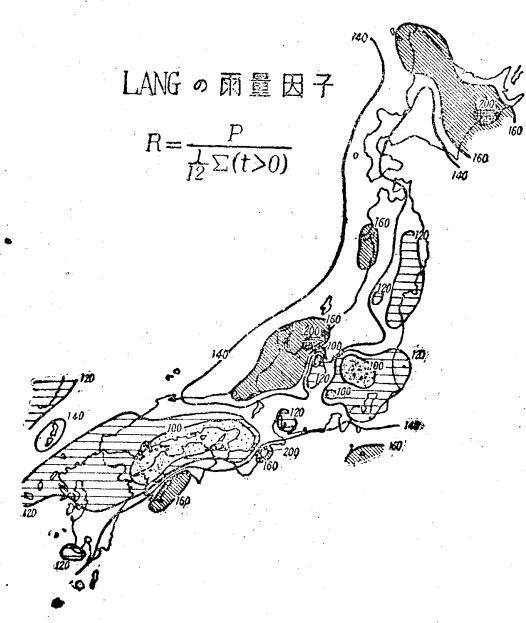

第 1 圖

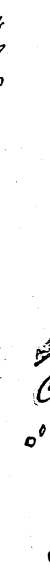

MARTONEの乾熼示数

$$
i=\frac{P}{T+10}
$$

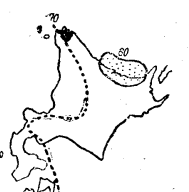

第 2 圆

降办量と蒸發量の比 $\Sigma \mathrm{P} / \Sigma \mathrm{e}$

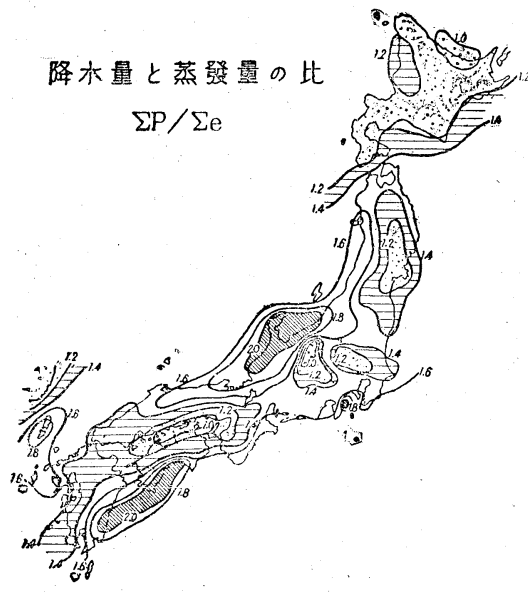

第 3 圖

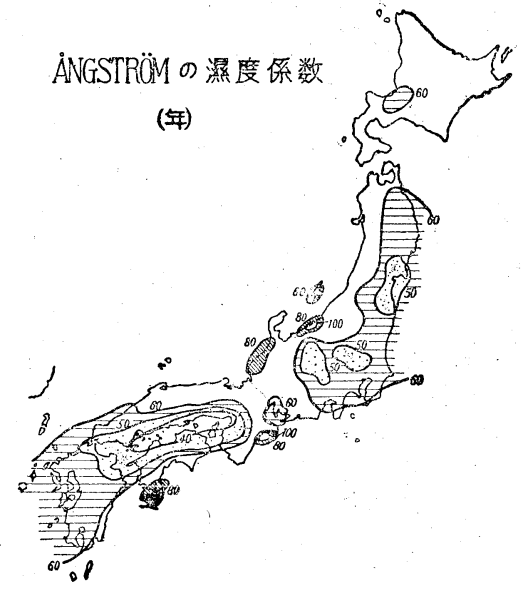

第 4 圖 
3.むすび 此等の示數について古來，一應との各ふについて意義付げが 行われ，純粹氣候學的裳量として重要覞やられて來ている。し加し此等は要

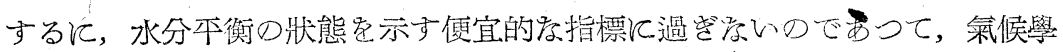

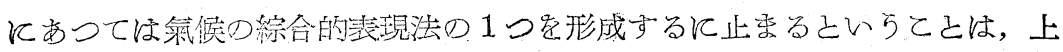

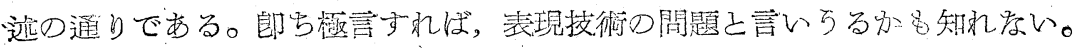
元來，乙の問題にあつては，土地全體からの蒸發量が正確に測定算出され店

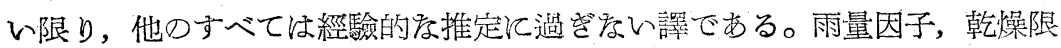
界, 乾燥示數等示數の形が多少巽り，常數はちがつているが, 原理的には全

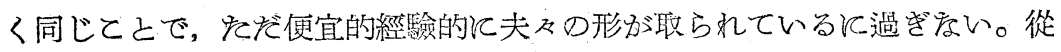

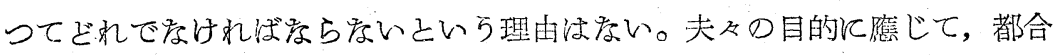
○よい示數を選べばよい。

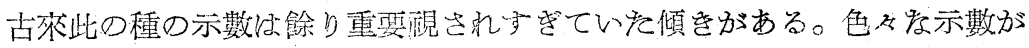

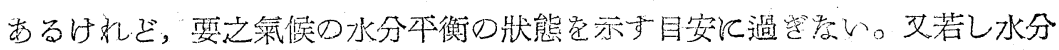

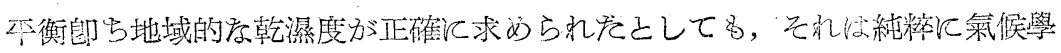

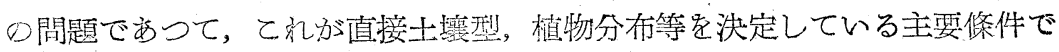

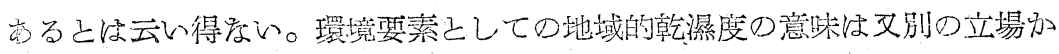

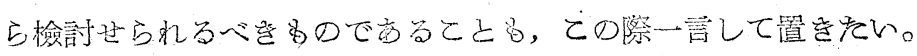

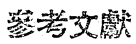

1) Transeau, E. N. : Forest Centers of Eastern America. Amer. Naturalist, 39 (1905) $875-889$.

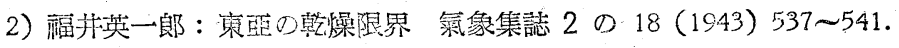

3) Meyer, A. : Über einige Zusammenhänge zwischen Klima und Boden in Europa. Chemie der Erde 2 (1926) 209-347.

Blanck, E. : Die Verwitterung in ihrer Abhängigkeit von den $\ddot{A}$ usserer Klimatischen Faktoren. Handb. d. Bodenlehre 3. (1930) 10-11.

4) Lang, R. : Verwitterung und Bodenbildung als Einführung der Bode- 
nkunde. 1920, Stuttgart, 107-123.

5) Köppen, W. : Klimaformel und reduzierte Regenmenge. Met. Zeit. 36 (1919) $1-7$

ibid : Die Regenmenge an der Trockengrenze. Met. Zeit. 39 (1922) 242 -244 .

ibid : Grundriss der Klimakunde. 1931, Berlin.

6) de Martonne, E. : Aréisme et indice d'aridité. Comp. Rend. 182 (1926) 1935.

ibid.: Une nouvelle fonction climatologique 1'indice d'aridite. La met. 1926.

7) Thornthwaite, C. W. : The climate of North America according to a new classification. Geogr. Rev. 21 (1931) 633-655.

8) Angström, A. : A coefficient of humidity of general applicability. Geogr. Ann. 18 (1936) 245-254.

9) Szymkiewiz, D. : Études climatologiques. Acta. bot. Poloniae. 2 (1925) No. 4

10) Wallén, A. : Eau tombeé, débit et évaporation dans la Suéde méridionale. Geogr. Ann. 9 (1927) 181-208.

（昭和23年12月23日受理）

On the Water Balance Problem as a Method of Representation of Climate

\section{Takesi Sekiguti}

Among the synthetical methods of representation of climate, there is an attempt to represent it by the water balance problem on each region, that is, to represent climate by the aridity of the area. We can understand that on considerably extensive area, the amount of water flows in is equal to that of flow out. Then the regional aridity can be considered as the difference of amount of precipitation and evaporation in that area. This amount is termed the effective precipitation. In these cases, the amount of precipitation is measurable 
anyway, but the amount of evaporation from a total area can not be measured exactly in ordinary way. Therefore the latter is only estimated from other various amounts easily measurable. There are following ways to estimate the regional evaporation amounts :

1. Evaporation amount from evaporimeter......Transeau (1905)

2. Deficit of saturation......Meyer (1926)

3. Air temperature …... Lang (1920) ; Rain factor, Köppen (19181931) ; Arid boundary, de Martonne (1926) ; Aridity index, Thornthwaite (1931) ; Preipitation effectiveness index (precipitation-e vaporation index or P.E index), Angström (1936) ; Coefficient of humidity, Hythergraph.

4. Air temperature, vapor tension and atmospheric pressure...... Szymkiewicz (1925)

5. Amounts of discharge in river......Wallén (1927)

Using some 'of these indexes, distribution maps of precipitation effectiveness in Japan have been drawn (Figs. 1-4). But the types of distribution are similar to each other. This is why, these indexes come from the same back ground of idea, that is, regional water balance or degrees of regional aridity and humidity. Up to the present, these indexes have been considered very important in climatology as purely climatological meaures, and it has been understood to calculate these indexes and to discuss on their geographical distribution is the climatology. But from above saying, it will be clear that these considerations are not true. 